\title{
Activation of CD4-Positive T Cells by Polysaccharide Fractions Isolated from the Cupressaceae Thuja occidentalis $L$. (Arborvitae)*
}

Sven H. Gohla ${ }^{1}$, Hans-Dieter Haubeck ${ }^{2}$, Silke Schrum ${ }^{1}$, Helga Soltau ${ }^{1}$, and Rolf D. Neth ${ }^{1}$

Various mitogens have been described which act on different subpopulations of mouse and/or human peripheral lymphocytes. In recent years it has been mainly Japanese and German research teams that have isolated polysaccharide fractions with immunomodulative properties $[1-3,17]$. In addition to fungal polysaccharides such as lentinan, schizophyllan, and PSK polysaccharide, which are basically in the experimental step of clinical use $[6,10,13]$, the focus of attention has mainly been on plants belonging to the asteracean family, such as Echinacea purpurea and E. angustifolia, where an increase in granulocyte phagocytosis is observable. Thuja occidentalis L., a Cupressaceae, has hardly been investigated up till now.

Several authors have demonstrated that allopathic extracts of this plant could be strong antiviral agents directed against plant and animal viruses [12, 3]. Polysaccharide fractions with molecular weights ranging between $5 \times 10^{5}$ and $1 \times 10^{6}$ and higher have been isolated from aqueous alkaline extracts of the herbal parts of Thuja occidentalis by ethanol precipitation and ultrafiltration using a Satorius Ultra Sart filtration cell [5].

1 Department of Clinical Chemistry, Medical University Clinic, UKE, Martinistraße 52, D2000 Hamburg, FRG

${ }^{2}$ Department of Clinical Chemistry, Medical University Clinic, Pauwelsstraße, D-5100 Aachen, FRG

* This study has been supported by the Karlund Veronika Carstens-Stiftung im Stifterverband für die Deutsche Wissenschaft
A high molecular weight subfraction of Thuja polysaccharides (TPSg) proved to be highly mitogenic in peripheral blood leukocytes (PBL) (Figs. 1, 2). It was shown using alkalic phosphatase anti-alcalic phosphatase (APAAP) [7, 8, 9] and Pappenheim staining methods that the mitogenic and cluster-forming activity of TPSg causes T-cell induction rather than induction of B-cells [11]. In detail, more than $90 \%$ of all TPSginduced blasts were shown to be Tpanpositive (T3, T11 and IOT1a marker); in contrast, Bpan-positive (CD22 marker) lymphoid cell induction occured in less than $4 \%$. In particular, TPSg was identified as a potent $\mathrm{T}$-cell mitogen which acts preferentially on the Okt4/Okt17-positive [14] T-cells (Fig. 3). As well as induction of the Okt4/Okt17 T-cell fraction, TPSg-induced generation of Okt16-positive immature T-cells/null cells was observed, whereas only a little stimulation of Okt8-positive T-cells was seen (Fig. 4). More than $75 \%$ of all TPSg-induced blast cells were shown to be Okt4/Okt17positive, whereas less than $5 \%$ of all blasts generated were Okt8-positive. About $20 \%-25 \%$ of all TPSg-induced blasts were shown to be immature T-cells or null cells.

The Okt4/Okt17-positive T-helper/inducer cell generation is connected with increased production of interleukin-2. Furthermore, TPSg-dependent enhanced expression of the interleukin-2 receptor $(75 \%)$ on the TPSg-triggered cells has been observed [15]. The cluster-forming ability and mitogenity of TPSg correlates well with $\left[{ }^{3} \mathrm{H}\right]$ thymidine uptake and seems to be interleukin-1 and interferon$\gamma$ dependent, as was shown by blocking 


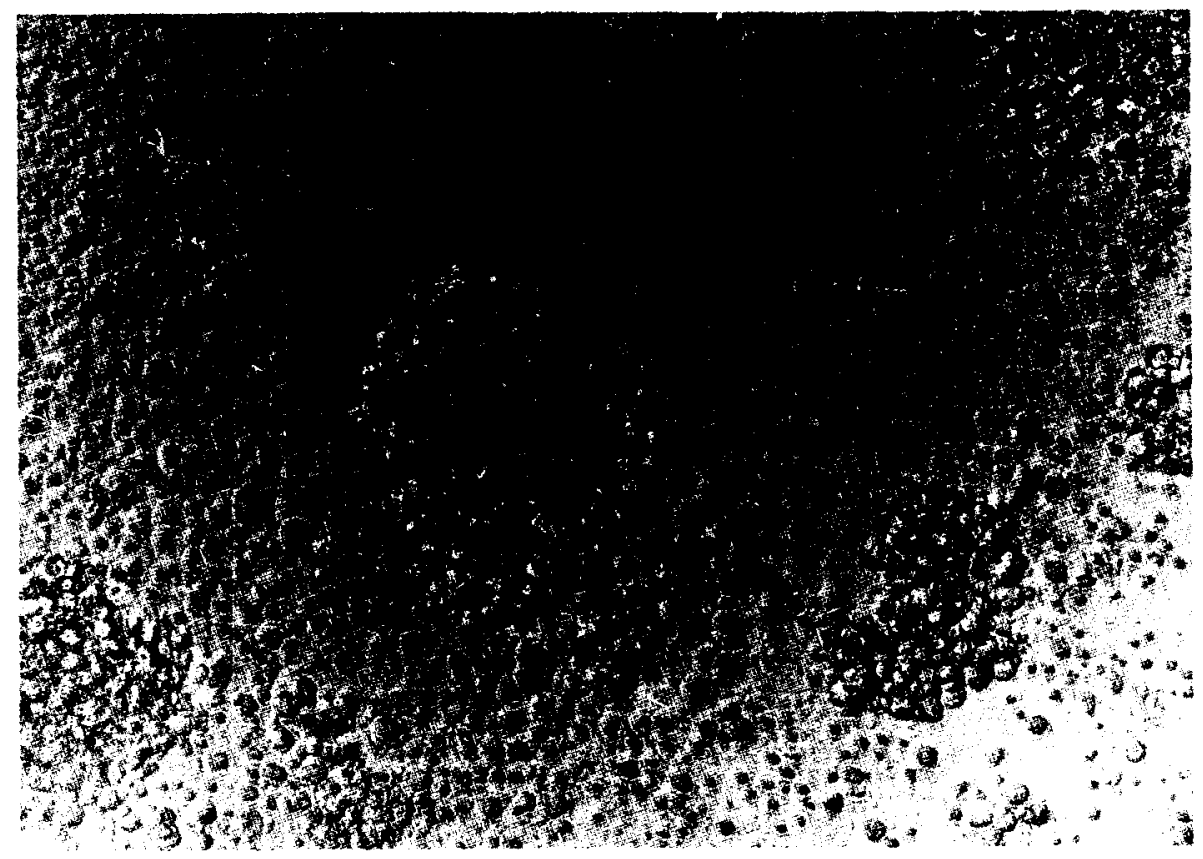

Fig. 1. Phase contrast micrograph of a 4-day-old culture of TPSg-triggered peripheral blood leukocytes. Magnification $550 \times$. Peripheral blood leukocytes (PBL) were obtained by means of density gradient centrifugation (Ficoll-Hypaque, Pharmacia). The "buffy coat" was harvested after having been centrifugated for $20 \mathrm{~min}$ and washed 5 times with phosphate buffered saline pH 7.2. $5 \times 10^{5}$ cells were seeded out per well in a flat bottomed 96-well microtiter plate with a final volume of $100 \mu$ l Dulbeccois modified Eagle's medium (DMEM) $+10 \%$ pooled human blood group AB serum. The cells were incubated with $100 \mu \mathrm{l} /$ well of a TPSg solution in DMEM $+10 \%$ pooled human $\mathrm{AB}$ serum with a final concentration of $1 \mathrm{mg} / \mathrm{ml}$ of TPSg

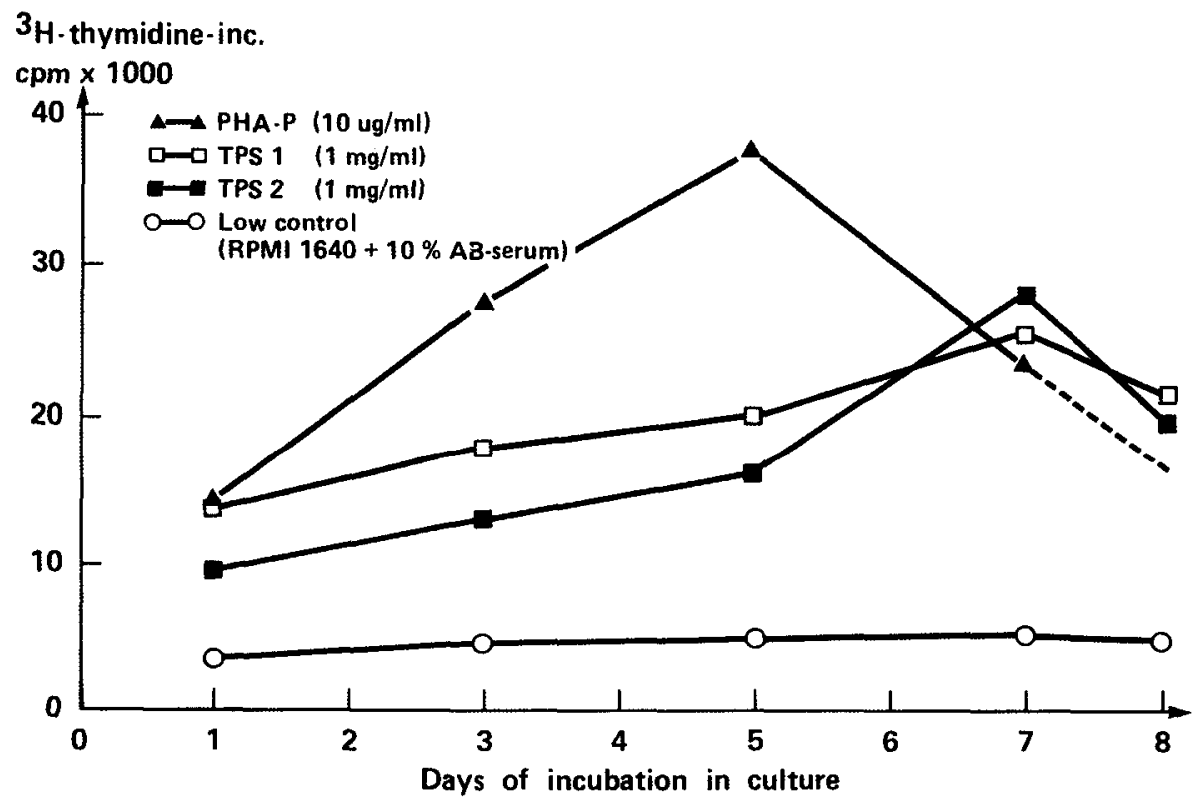

Fig. 2. Kinetics of the DNA-synthesis in PBL and the influence of TPSg. Thuja polysaccharide fraction. $5 \times 10^{5} \mathrm{PBL}$, resuspended in RPMI 1640 , supplement with $6 \%$ fetal calf serum (FCS) and $4 \%$ human $\mathrm{AB}$ serum, were incubated at a final concentration of $1 \mathrm{mg} / \mathrm{ml}$ per well in a flat bottomed, microtiter plate. On days $0,2,4,6$, and $8,0.5 \mu \mathrm{Ci} / 50 \mu \mathrm{l}$ RPMI 1640 was added for the last $12 \mathrm{~h}$ of incubation. Afterwards the cells were harvested (Scatron cell harvester) and the DNA synthesis rate was measured in a $\beta$-liquid scintillation counter. Supplemented medium was used as low control and Phytohemagglutinin. PHA-P, final concentration $10 \mu \mathrm{g} / \mathrm{ml}$, was used as high control. Both controls were incubated under the same conditions as the TPSg cultures. All cultures were performed in triplicate. The results shown are the mean values of two experiments 


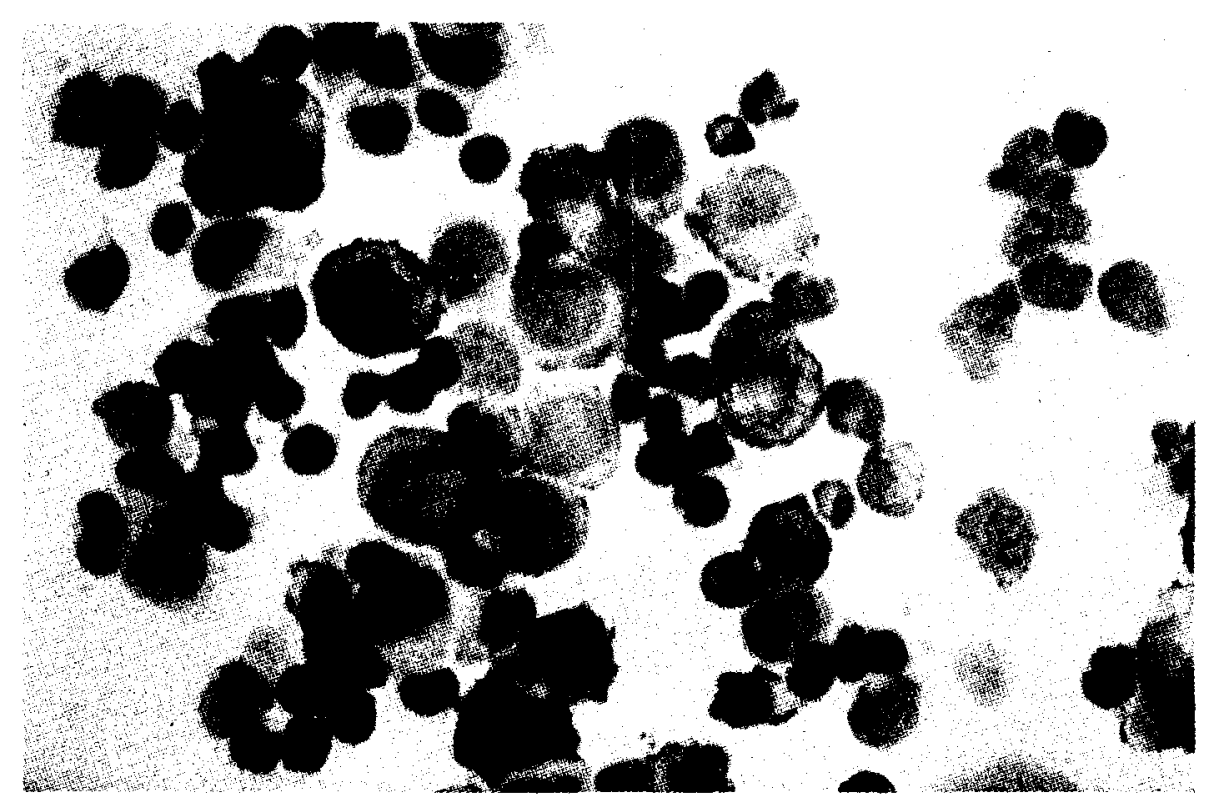

Fig. 3. Anti-Okt4 alkaline phosphatase anti-alkaline phosphatase (APAAP) staining of TPSgtriggered peripheral blood leukocytes. Magnification $630 \times$. Air-dried cells were stained by the APAAP method (Erber et al.). The cells were fixed for 1 min with an acetone, methanol and formaldehyde $(95: 95: 10)$ fixative. The following steps were carried out at room temperature $\left(25^{\circ} \mathrm{C}\right)$ in a humidified chamber. The first CD4 + surface antigen specific antibody (Dakko, cat. no. M716, Denmark) was incubated for $30 \mathrm{~min}$. Subsequent washing was done using TBS (Tris-buffered saline, $\mathrm{pH} \mathrm{7.6)}$ unless otherwise indicated. After washing with TBS $(1 \mathrm{~min})$, the second incubation step with rabbit anti-mouse (RaM) bridge antibodies (Dakko, cat. no. Z259) was carried out for another $30 \mathrm{~min}$. After washing, the third incubation with APAAP complex (Dakko, cat no. D651) was carried out for another $30 \mathrm{~min}$. The quality of the staining can be improved if all incubation steps are done twice. The "fast red" method was used as a detection system. The sample was washed after APAAP incubation and was incubated with the substrate [dimethylformamide $(200 \mu \mathrm{l})$; levamisole $(30 \mu \mathrm{l})$; "fast red" $(10 \mathrm{mg}) ; 0.1 \mathrm{M}$ Tris, $\mathrm{pH}$ 8.2; naphthol-AS-MX-phosphate $(2 \mathrm{mg})]$ for a period of $30 \mathrm{~min}$. After washing counterstaining with hematoxylin was done (1 min). All slides were placed in Apathy's mountian medium, Highman's modification

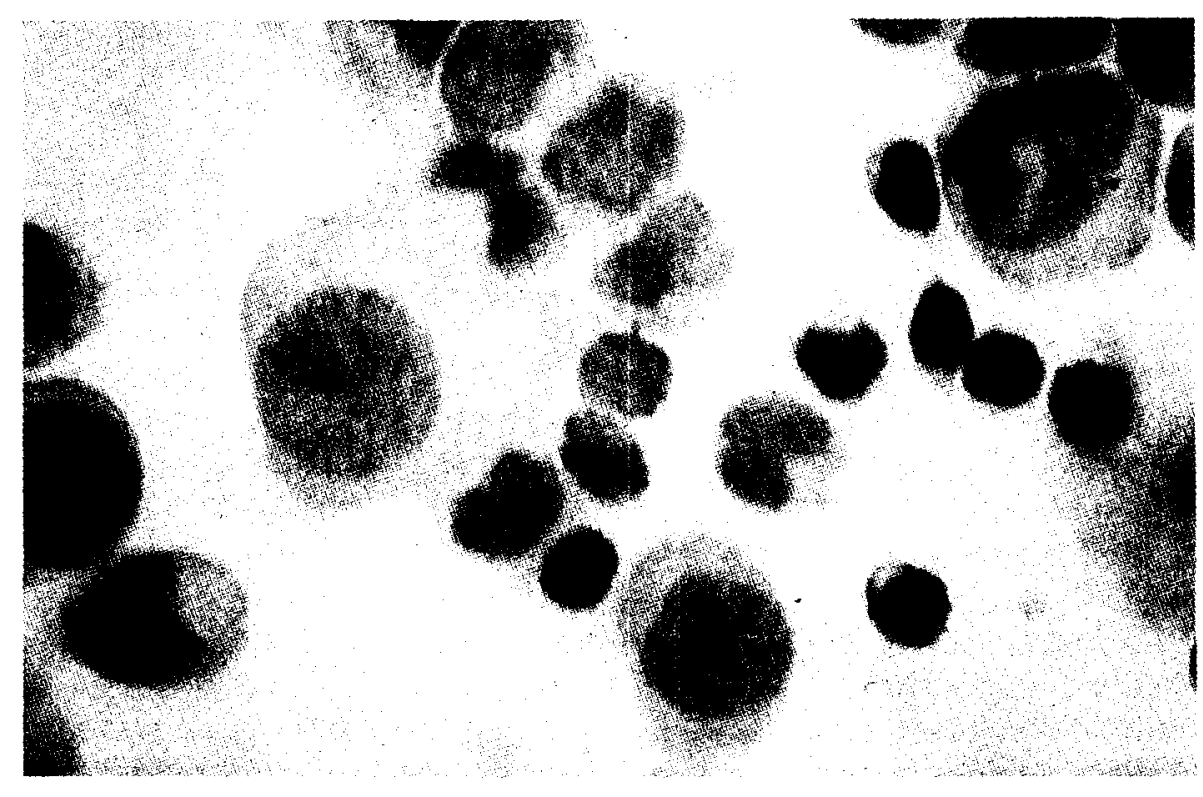

Fig. 4. Anti-T-suppressor/cytotoxic staining (OKT8 marker). Magnification $630 \times$. For details of methods used see Fig. 3 


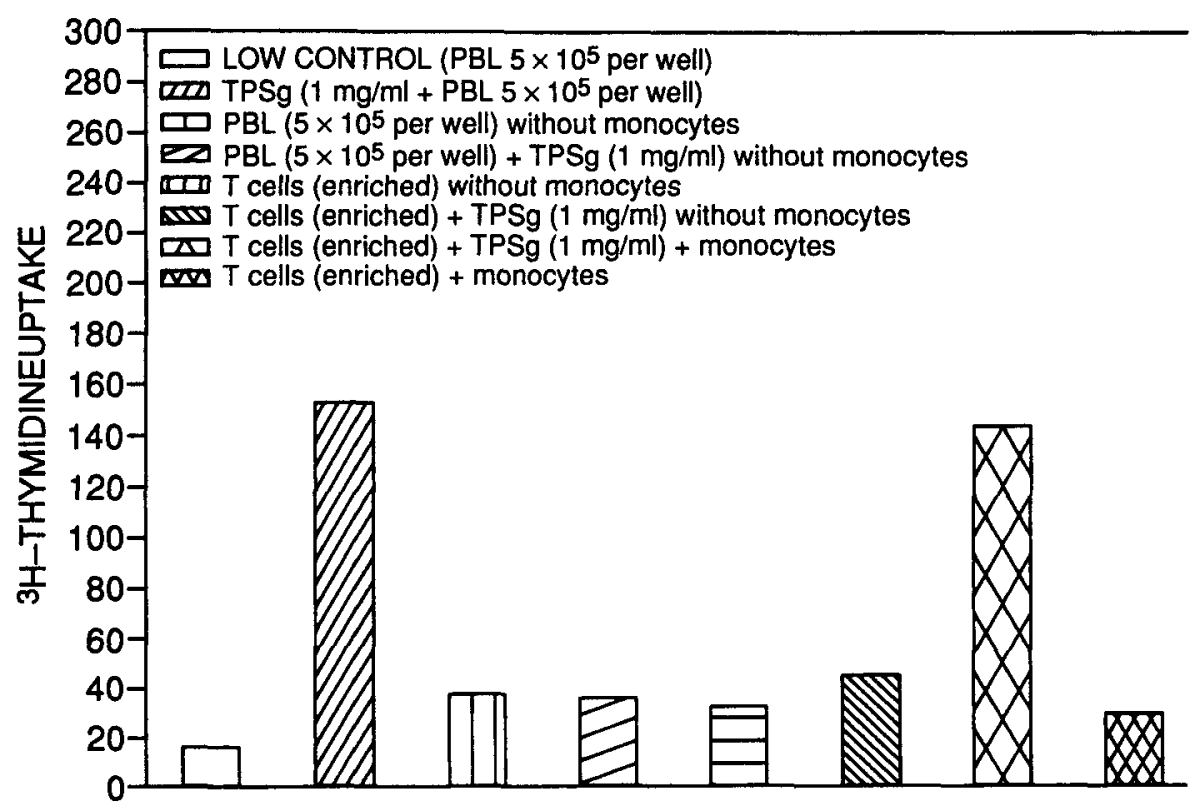

Fig. 5. The influence of TPSg and enriched T-lymphocytes in the presence or absence of peripheral blood monocytes. The peripheral blood monocytes were separated from the lymphocyte fraction by the monocyte adherence method described elsewhere and incubated separately under standard conditions. $5 \times 10^{5} \mathrm{PBL}$ and $5 \times 10^{5}$ enriched T-cells were incubated with TPSg medium, final concentration $1 \mathrm{mg} / \mathrm{ml}$, or with non-lectin-supplemented complete medium. The T-cell enrichement was performed according to the standard procedure using nylon wool as separation column. The T-cell fraction was obtained by rinsing the nylon wool 2 times with cold PBS. It could be shown that TPSg only works as a mitogen on PBL and enriched T-cell fractions in the presence of autologous monocytes. All results are mean values of two independent experiments. All concentrations per experiment were determined in triplicate

the mitogenic effect with interleukin-1and interferon- $\gamma$-specific antibodies. It was also shown that Okt4-positive T-cell induction depends on the presence of autologous monocytes/macrophages (Fig. 5). Whether it is possible to use this polysaccharide fraction as an adjuvant in the therapy of immune deficiency syndromes and cancer must now be further investigated.

\section{References}

1. Beuscher N (1982) Über die medikamentöse Beeinflussung zellulärer und humoraler Resistenzmechanismen im Tierversuch. Arzneimittelforschung 32:134ff

2. Beuscher $N$ (1982) Über die medikamentöse Beeinflussung zellulärer und humoraler Resistenzmechanismen im Tierversuch. III. Steigerung der Leukozytenmobilisation bei der Maus durch pflanzliche Reizkörper. Arzneimittelforschung $30: 821 \mathrm{ff}$
3. Beuscher N, Kopanski W (1986) Purification and biological characterization of antiviral substances from Thuja occidentalis L. In: $37^{\text {th }}$ Annual congress on medical plant research, Hamburg, 22-27 Sept. 1986, Abstract of short lectures and poster presentation, Planta Medica, Thieme Verlag, $\mathrm{p} 75$

4. Beuscher N, Beuscher H, Otto B, Schäfer B (1977) Über die medikamentöse Beeinflussung zellulärer und humoraler $\mathrm{Re}$ sistenzmechanismen im Tierversuch. II. In vitro Untersuchungen an PeritonealLeukozyten und Seren der Ratte. Arzneimittelforschung 27:1655 ff

5. Caldes G, Prescott B, Thomas II CA, Bahr PJ (1981) Characterization of a polysaccharide from Carthamus tinctorius that cross reacts with type III pneumococcae polysaccharide. J Gen Appl Microbiol $27: 157 \mathrm{ff}$

6. Chihara G, Maeda J, Hamuro J, Tahuma S, Fumiko F (1969) Inhibition of mouse sarcoma 180 by polysaccharides from Lentinus etodes (Berk.) Sing. Nature 222: $687 \mathrm{ff}$

7. Cordell JL, Falini B, Erber WN (1984) Immunoenzymatic labeling of monoclon- 
al antibodies using immune complexes of alkaline phospatase and monoclonal antialkaline phosphatase (APAAP complexes). J Histochem Cytochem 32:219 ff

8. Erber WN, Pinching AJ, Mason DY (1984) Immunocytochemical detection of $\mathrm{T}$ and $\mathrm{B}$ cell populations in routine blood smears. Lancet I: $1042 \mathrm{ff}$

9. Erber WN, Mynheer LC, Mason DY (1986) APAAP labelling of blood and bone-marrow samples of phenotyping leukemia. Lancet I:761 ff

10. Fujimoto S, Takahashi $M$, Minami $T$, Ishigami H, Miyazaki M, Itoh K (1979) Clinical value of immunotherapy with OK432 or PS-K for stomach cancer patients. Jpn J Surg 9:190 ff

11. Gohla S, Haubeck H-D, Neth RD (1988) Mitogenic activity of high molecular polysaccharide fractions from the plant "Thuja occidentale L.". I. Monocyte-dependent induction of $\mathrm{CD}^{+}$T-helper cells. Leukemia 2:528-533
12. Khurana PSM (1971) Effect of homoeopathic drugs on plant viruses. Planta Medica 20:142ff

13. Maeda JY, Chihara G (1971) Lentinan, a new immuno-accelerator of cell-mediated responses. Nature 229:634 ff

14. Thomas Y, Rogozinski L, Rothman P, Rabbani LE, Andrews S, Irigoyen $\mathrm{OH}$, Chess L (1982) Further dissection of the functional heterogeneity within the $\mathrm{OKT}_{4}^{+}$and $\mathrm{OKT}^{+}$human t-cell subsets. J Clin Immunol 2:85 ff

15. Uchiyama $T$, Nelson $D L$, Fleidher TA, Waldmann TA (1981) A monoclonal antibody (anti-TAC) reactive with activated and functionally mature human T-cells. $J$ Immunol 126:1398-1404

16. Vollmar A, Schäfer W, Wagner H (1986) Immunologically active polysaccharides of Eupatorium cannabinum and Eupatorium perfoliatum. Phytochemistry $25: 377 \mathrm{ff}$ 